\title{
Breed-specific ecobiometry and ultrasound factors predictive of fetal maturity in healthy English Bulldog bitches subjected to elective cesarean section
}

\author{
Ecobiometria raça específica e fatores ultrassonográficos preditivos de maturidade fetal em cadelas \\ saudáveis da raça Bulldog Inglês submetidas à cesariana eletiva \\ Ecobiometría específica de la raza y factores predictivos de ultrasonido de la madurez fetal en \\ perras sanas de la raza Bulldog Inglés para cesárea electiva
}

Luana Azevedo de Freitas ORCID: https://orcid.org/0000-0002-1851-2851 Universidade Estadual do Ceará, Brasil E-mail: lualaf@hotmail.com

Paula Priscila Correia Costa ORCID: https://orcid.org/0000-0001-6421-0689 Universidade Federal de Pelotas, Brasil E-mail: paulapriscilamv@yahoo.com.br

Stefanie Bressan Waller ORCID: https://orcid.org/0000-0001-6719-1794 Universidade Federal de Pelotas, Brasil E-mail: waller.stefanie@yahoo.com.br

Thaissa Gomes Pellegrin ORCID: https://orcid.org/0000-0002-6359-7989 Universidade Federal de Pelotas, Brasil

E-mail: thaissagpel@gmail.com

Eduardo Gonçalves da Silva

ORCID: https://orcid.org/0000-0001-8951-9316 Universidade Federal de Pelotas, Brasil

E-mail: goncalves-eduardo@outlook.com

Michaela Marques Rocha

ORCID: https://orcid.org/0000-0002-5316-459X Universidade Federal de Pelotas, Brasil

E-mail: michaelamr98@ @otmail.com

Caroline Castagnara Alves

ORCID: https://orcid.org/0000-0001-5077-9479 Universidade Federal de Pelotas, Brasil

E-mail: caro1090898@gmail.com

Francesca Lopes Zibetti

ORCID: https://orcid.org/0000-0002-9282-3762 Universidade Federal de Pelotas, Brasil

E-mail: franlz134@yahoo.com.br

Wesley Lyeverton Correia Ribeiro ORCID: https://orcid.org/0000-0002-2784-0013 Universidade Federal do Ceará, Brasil E-mail: wesleylyeverton@yahoo.com.br

Lúcia Daniel Machado da Silva ORCID: https://orcid.org/0000-0001-9793-1968 Universidade Estadual do Ceará, Brasil

E-mail: lucia.daniel.machado@ hotmail.com

\begin{abstract}
The aims of the current study are to build an equation to predict gestational age (GA) and to compare ultrasound parameters indicative of delivery in healthy English Bulldog bitches subjected to elective cesarean section. Sixteen pregnant female dogs were included in the study. Inner chorionic cavity (ICCDD) and biparietal (BPD) diameters were measured at 30 and 50 days after artificial insemination, respectively, to estimate GA at embryonic and fetal stages. BPD, heart rate (HR), and intestinal peristalsis were measured at $48 \mathrm{~h}, 24 \mathrm{~h}$, and 6 hours before delivery to compare fetal development. ICCD and BPD values were subjected to linear regression and parameters predictive of elective cesarean section were compared through Student's t-test before delivery. The number of conceptuses did not influence pregnancy duration. Both ICCD and BPD were significantly correlated to GA; their formulas presented accuracy of \pm 1 and \pm 2 days, respectively, in comparison to that of progesterone dosage. Based on the comparative
\end{abstract}


ultrasound assessment, BPD has significantly increased from $48 \mathrm{~h}$ to $6 \mathrm{~h}$ before delivery ( $\geq 3 \mathrm{~cm}$ ), regardless of the number of pups, whereas HR has significantly decreased within $6 \mathrm{~h}$ before delivery (HR $<200 \mathrm{bpm}$ ). There was not statistically significant difference in parameter "intestinal peristalsis" among measurement times. The current study is pioneer in highlighting that measuring ICCD and BPD in the formula is a useful tool to predict GA in the herein investigated breed and that fetal parameters such as BPD and HR are fetal maturity predictors.

Keywords: Canine bitches; Breed; Cesarean section; Fetuses; Gestation; Ultrasound.

\begin{abstract}
Resumo
Objetivamos construir uma equação para predizer a idade gestacional (IG) e comparar os parâmetros ultrassonográficos indicativos de parto em cadelas Bulldog Inglês saudáveis submetidas à cesariana eletiva. Dezesseis cadelas grávidas foram incluídas neste estudo. Os diâmetros internos da cavidade coriônica (DICC) e diâmetro biparietal (DBP) foram medidos, respectivamente, 30 dias e 50 dias após a inseminação artificial para estimar o IG nas fases embrionária e fetal. Para comparar o desenvolvimento fetal, DBP, frequência cardíaca (FC) e peristaltismo intestinal foram medidos em $48 \mathrm{~h}, 24 \mathrm{~h}$ e 6 horas antes do parto. Os valores de DICC e DBP foram submetidos à regressão linear e os parâmetros preditivos para cesárea eletiva foram comparados pelo teste t de Student para préparto. O número de conceptos não influenciou na duração da gravidez. Ambas as medidas de DICC e DBP foram significativamente correlacionadas com a IG, cuja acurácia das fórmulas foi de \pm 1 e \pm 2 dias em relação à dosagem hormonal de progesterona. Na avaliação ultrassonográfica comparativa, a DBP aumentou significativamente de 48 horas para 6 horas antes do parto $(\geq 3 \mathrm{~cm})$, independentemente do número de filhotes, enquanto a $\mathrm{FC}$ diminuiu significativamente nas 6 horas pré-parto $(\mathrm{FC}<200 \mathrm{bpm})$. Não houve diferença estatística no parâmetro peristaltismo intestinal entre os tempos. Pela primeira vez, os resultados destacaram que medir DICC e BPD na fórmula é uma ferramenta útil para prever a IG nesta raça e que os parâmetros fetais BPD e FC são preditores da maturidade fetal.

Palavras-chave: Cadelas; Raça; Cesárea; Fetos; Gestação; Ultrassom.
\end{abstract}

\title{
Resumen
}

Nuestro objetivo fue construir una ecuación para predecir la edad gestacional (EG) y comparar los parámetros ecográficos indicativos del parto en perras Bulldog Inglés sanas sometidas a cesárea electiva. En este estudio se incluyeron dieciséis perras preñadas. Se midieron los diámetros internos de la cavidad coriónica (DICC) y el diámetro biparietal (DBP), respectivamente, 30 días y 50 días después de la inseminación artificial para estimar el EG en las etapas embrionaria y fetal. Para comparar el desarrollo fetal, se midieron la DBP, la frecuencia cardíaca (FC) y la peristalsis intestinal a las 48 h, 24 h y 6 h antes del parto. Los valores de DICC y DBP se sometieron a regresión lineal y los parámetros predictivos para la cesárea electiva se compararon mediante la prueba " $t$ " de Student para el preparto. El número de concepciones no influyó en la duración del embarazo. Tanto las mediciones de DICC como de BPD se correlacionaron significativamente con EG, cuya precisión de la fórmula fue de \pm 1 y \pm 2 días en relación con la dosis hormonal de progesterona. En la evaluación ecográfica comparativa, la DBP aumentó significativamente de 48 horas a 6 horas antes del parto $(\geq 3 \mathrm{~cm})$, independientemente del número de crías, mientras que la FC disminuyó significativamente a las 6 horas antes del parto (FC <200 pulsaciones por minuto). No hubo diferencia estadística en el parámetro de peristalsis intestinal entre tiempos. Por primera vez, los resultados destacaron que medir DICC y BPD en la fórmula es una herramienta útil para predecir la EG en esta raza y que los parámetros fetales BPD y FC son predictores de madurez fetal.

Palabras clave: Perras; Raza; Cesárea; Fetos; Gestación; Ultrasonido.

\section{Introduction}

Parturition date prediction is an important factor to help planning cesarean sections, even in unknown-coverage cases. It is known that gestation duration in domestic dogs can range from 58 to 71 days after the mating day (Concannon et al., 1989). This range may be influenced by sperm longevity in females' reproductive tract, as well as by the interval between estrus onset and ovulation, and the release of immature oocytes, whose maturation takes place within 72 hours in the reproductive tract (Concannon et al., 1989; Feldman \& Nelson, 2003; Concannon, 2011).

Ultrasound is the most common method used as gestational assessment tool, since it is simple, accessible, reliable, non-invasive, non-expensive (Davidson \& Baker, 2009; Lamm \& Makloki, 2012; Nyland \& Mattoon, 2015, De Carvalho et al., 2021), and enables monitoring embryonic and fetal development. This method enables diagnosing early pregnancy, identifying gestational abnormalities, assessing fetal viability and development (Lopate, 2008; Davidson \& Baker, 2009; Lamm \& Makloki, 2012; Nyland \& Mattoon, 2015; Freitas et al., 2016), as well as defining gestational age based on fetal structures and ecobiometry (Luvoni \& Beccaglia, 2006). 
It is essential determining gestational age in an accurate manner by applying transabdominal ultrasound in canine bitches to help planning parturition and postpartum management, carrying out elective cesarean section, as well as knowing the complete fetal formation time (Kutzler et al., 2003). Ecobiometric studies have been used to estimate gestational age in different small-, medium-, and large-sized dog breeds (Lopate, 2008; Michel et al., 2011; Beccaglia \& Luvoni, 2012), such as Labrador Retriever and Golden Retriever (England et al., 1990), German Shepherd (Groppetti et al., 2015), Jack Ru ssell terrier and Golden Retriever-Irish Setter crossbreed (Luvoni \& Grioni 2000).

Ecobiometry is also a useful tool to estimate the likely delivery date based on anatomical measurements taken of conceptuses (Luvoni \& Grioni 2000) at different pregnancy times (Groppetti et al., 2015). However, ecobiometric data are not always applied to all canine breeds, due to great diversity in species' size and different conformational types. Recent study has applied a new approach to gestational ultrasound examination given the need of planning elective cesarean sections for brachycephalic breeds such as English Bulldog, miniature breeds such as Yorkshire and Chihuahua (O'Niell et al., 2017), among other breeds such as Boston Terrier and Scottish Terrier, who often have obstructive dystocia due to fetal-maternal disproportion (Jutkowitz, 2005; Linde-Forsberg, 2005).

Fetal maturity must be taken into consideration at the time to make decisions about elective cesarean section, since it enables identifying fetal structures as to their defined architecture (Nyland \& Mattoon, 2015). Intestinal peristalsis (Gil et al., 2015), reduced heart rate (Lopate, 2008; Davidson \& Baker, 2009; Lamm \& Makloki, 2012; Gil et al., 2014; Nyland \& Mattoon, 2015), as well as reduced umbilical artery resistivity index (Giannico et al., 2015) are also factors that should be taken into account at the time to make decisions about cesarean section.

The aforementioned variables must be analyzed together, rather than in separate, to enable defining the proper time for elective cesarean section (Gil et al., 2015). The set of information often generates uncertainties about breeds lacking detailed information. Among them, one finds English Bulldog, whose high dystocia incidence justifies the frequency of elective cesarean sections animals belonging to this species are often subjected to (Dobak et al., 2018).

The aims of the current study were to build an equation to predict gestational age at embryonic and fetal stages and to compare ultrasound parameters indicative of delivery in English Bulldog bitches subjected to elective cesarean section.

\section{Methodology}

\subsection{Research}

The current research is an experimental study of quantitative nature (Pereira et al., 2018) aimed at evaluating ultrasound data and at building an equation predictive of gestational age in canine bitches subjected to elective cesarean section.

\subsection{Experimental Animals and Procedure}

Sixteen $(n=16)$ pregnant English Bulldog bitches were evaluated in the current study. All animals were healthy, presented weight ranging from 20 to $25 \mathrm{~kg}$, were in the age group 1 year and 8 months to 4 years, and belonged to private kennels in Ceará State (Northeastern Brazil). They fed on commercial granulated dog food and had access to water ad libitum. They had known reproductive history and/or presented normal standards in clinical (physical inspection), laboratory (blood count), abdominal and pelvic ultrasound assessments. All experimental procedures were approved by the Ethics Committee on Animal Experimentation (Comitê de Ética para Uso Animal - CEUA, Ceará State University, Fortaleza, CE, Brazil), under protocol number 5999508/2015.

All canine bitches were clinically followed-up, based on vaginal cytology and hormonal dosage. Inseminations with fresh male semen presenting proven fertility and good seminal quality were performed for three consecutive days; samples 
presented progesterone hormone levels higher than, or equal to, $2 \mathrm{ng} / \mathrm{mL}$. ELFA quantitative method was used in assays performed for progesterone measurement purposes (Enzyme Linked Fluorescent Assay; MiniVidas, bioMérieux). Luteinizing hormone (LH) peak was set as day 0 (zero) and defined when progesterone levels were equal to, or higher than, $2 \mathrm{ng} / \mathrm{ml}$ (Concannon, 2011).

\subsection{Two-dimensional ultrasound evaluations}

Ultrasound examinations were performed for consecutive six months in private kennels located in the metropolitan region of Fortaleza City, Ceará State (Northeastern Brazil). They were carried out by the same operator with the aid of Logiq E (General Electronics, GE) 8-13 MHz multifrequency linear probe (LA523 reference). Evaluations were preferably carried out in the morning, in animals who fasted for at least eight hours. Animals were kept in supine position, without sedation. Their abdominal and pelvic regions were previously shaved and water-soluble acoustic gel was used to perform the exam.

\subsubsection{Experimental design number 1 to predict gestational age}

After confirmatory pregnancy results, canine bitches were evaluated at two different times: the first evaluation was carried out at 30 days after artificial insemination (AI) and the second evaluation, at 50 days after AI. Both assessments were performed to predict gestational age through the application of mathematical equations at embryonic and fetal stages through linear regression and ANOVA (Software R 2.15.1).

ICCD values were measured at 30 days after AI, by taking into consideration the mean of two inner chorionic cavity diameter measurements taken at $90^{\circ}$ cross-section angles, close to the trophoblastic reaction; embryonic vesicles were spherical and presented well-defined margins. BPD values, in their turn, were assessed at 50 days after IA; they were obtained through the longitudinal section of the skull and measured by taking into consideration the parallel distance between parietal bones (Figure 1). All measurements were taken in two different conceptuses located more cranial to the birth canal in each uterine horn, and their application to build the equations was based on the mean value of these measurements (Luvoni, 2013).

Figure 1 - Sonograms performed at 30 days after artificial insemination (AI) to measure inner chorionic cavity diameter (A), as well as at 50 days after AI to measure biparietal diameter (B) in English Bulldog bitches.
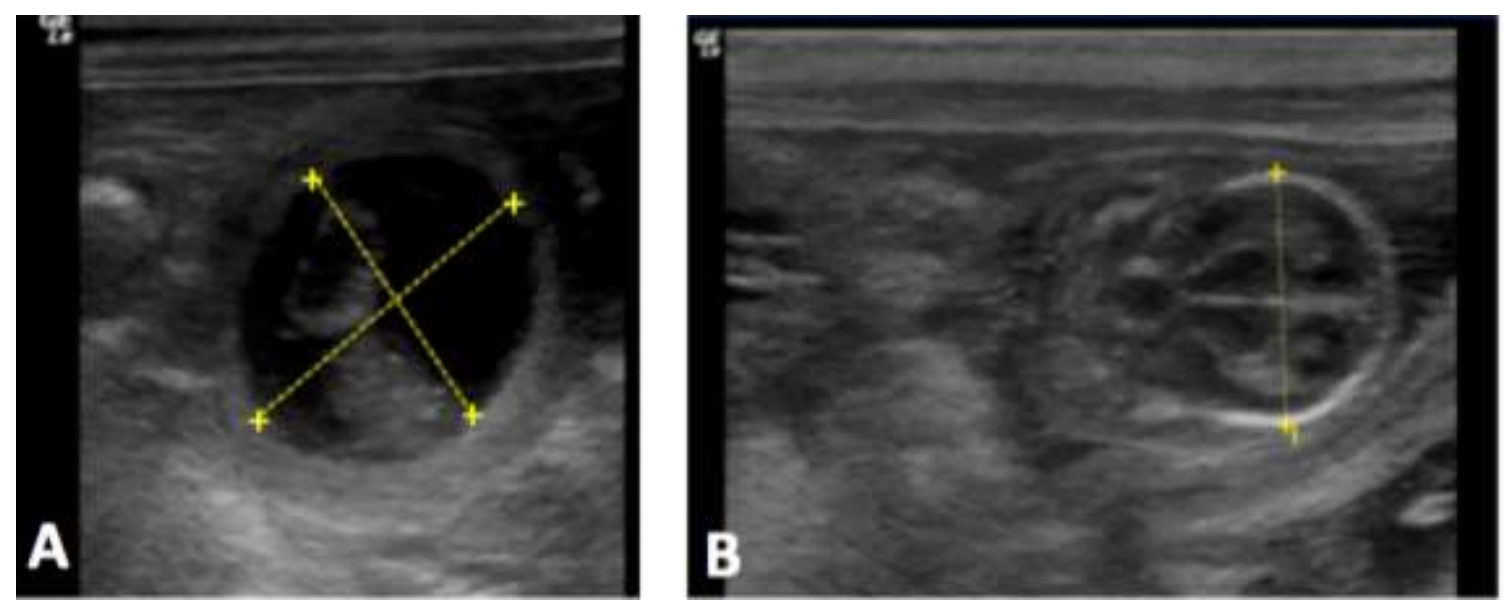

Source: Authors.

\subsubsection{Experimental design number 2 for fetal growth evaluation}

Ultrasound assessments were performed at $48 \mathrm{~h}, 24 \mathrm{~h}$, and $6 \mathrm{~h}$ before surgical intervention, based on two-dimensional findings of fetal maturity. At least five fetuses from each pregnant dog were evaluated when litter size was equal to, or larger 
than, five fetuses. All conceptuses were measured when litter comprised less than 5 individuals. The evaluation procedure took into consideration the smallest and largest fetuses in the same pregnancy. Biparietal diameter was measured as described in experiment n. 1; it was used as parameter to assess fetal growth.

Fetal functionality parameter was evaluated through intestinal peristalsis, which was classified based on bowel movement intensity. Peristalsis was classified as absent (score 0), when bowel movement was not identified; as light (score 1), when this movement was only seen in a few segments of it at reduced intensity; as moderate (score 2), when movement was identified in multiple segments, although at reduced intensity; and as evident (score 3), when bowel movement was identified in multiple segments at evident intensity.

Heart rate was measured as parameter to assess fetal viability and stress. All fetuses presented parietal stratification and compartmentalization of cardiac chambers; this outcome has evidenced fetal maturity. All cesarean sections were performed in surgical environment by using inhalational anesthetic. Apgar score was applied to newborn puppies to prove ultrasound assessment effectiveness in indicating successful cesarean sections.

\subsection{Statistical analysis}

Results were expressed as mean and standard deviations. All tests were performed in R Software version 2.15.1. Linear regression method and ANOVA were used to calculate the gestational age based on measurements taken in evaluations carried out at 30 and 50 days after artificial insemination. The number of conceptuses was assessed based on their influence on pregnancy duration. The accuracy of values that have resulted from formulas generated to estimate gestational age was compared to that of pregnancy duration values obtained through serum progesterone dosage using Pearson's test. Parameters such as fetal growth (biparietal diameter), heart rate, and intestinal peristalsis $48 \mathrm{~h}, 24 \mathrm{~h}$, and $6 \mathrm{~h}$ before delivery were subjected to ANOVA and Student's t-test in order to find factors associated with fetal maturity; $P$ values $\leq 0.05$ were considered significant.

\section{Results}

\subsection{Ultrasound findings}

Ultrasound assessment time ranged from 20 to 30 minutes: 25 minutes, on average. All canine bitches presented normal gestational course without complications during the intraoperative and postoperative periods. Two of the 16 evaluated English Bulldog bitches went into labor before surgical intervention; there was no neonatal death (n. 6 and 10). Nulliparous (02/16), primiparous (03/16), and multiparous (11/16) canine bitches, whose age ranged from 16 to 49 months, were evaluated, as shown in Table 1. If one considers the LH hormone peak as day zero, pregnancy duration ranged from 58 to 63 days (60 \pm 1.35 days).

Litter size ranged from two to nine puppies; in total, 89 puppies were born during the current study. Two of them presented prenatal death due to mummification (fetuses born from dogs n. 3 and 7), and six presented birth abnormalities featured by fetal hydrops, eventration, and cleft lip (fetuses born from dogs n. 1, 4, 7, 10, 12 and 16). All fetal abnormalities were identified through ultrasound, except for cleft lip. Minimum and maximum Apgar scores were 9 and 10, respectively. 
Table 1 - Gestational findings recorded for 16 healthy English Bulldog bitches and respective number of conceptuses born in the litter.

\begin{tabular}{ccccc}
\hline Animals & Age (months) & Parity & $\begin{array}{c}\text { Pregnancy duration } \\
\text { (days) }\end{array}$ & $\begin{array}{c}\text { N. of conceptuses born in the } \\
\text { litter }\end{array}$ \\
\hline 1 & 24 & Primiparous & 61 & 3 \\
2 & 33 & Multiparous & 60 & 5 \\
3 & 16 & Nulliparous & 61 & 4 \\
4 & Multiparous & 63 & 6 \\
5 & 48 & Multiparous & 59 & 9 \\
6 & 38 & Multiparous & 61 & 5 \\
7 & 26 & Primiparous & 60 & 8 \\
8 & 24 & Multiparous & 62 & 7 \\
9 & 33 & Multiparous & 60 & 2 \\
10 & 49 & Multiparous & 59 & 9 \\
11 & 44 & Multiparous & 58 & 3 \\
12 & 40 & Nulliparous & 60 & 5 \\
13 & 20 & Multiparous & 63 & 4 \\
14 & 48 & Primiparous & 61 & 3 \\
15 & 26 & Multiparous & 58 & 7 \\
16 & 43 & Multiparous & 62 & 9 \\
\hline
\end{tabular}

*N. of days after LH peak, which was considered as day 0.

Source: Authors.

\subsection{Formula used to predict gestational age in English Bulldog bitches}

Equations built for embryonic ecobiometry assessment at 30 days after AI and for fetal ecobiometry assessment at 50 days after AI (Table 2) were useful to predict gestational age at embryonic and fetal stage. Both ICCD and BPD were significantly and linearly correlated to gestational age. The accuracy of values obtained through these formulas was \pm 1 and \pm 2 days, respectively, in comparison to pregnancy duration estimated through hormonal dosage. Moreover, the number of conceptuses did not influence pregnancy duration $(P>0.05)$.

Findings recorded in experiment $n .1$ have shown that the formulas used to measure fetal structures enabled accurately predicting gestational age at embryonic and fetal stage in English Bulldog bitches.

Table 2 - Equations and correlation coefficients (r) of ultrasound measurements associated with gestational age in 16 pregnant English Bulldog bitches.

\begin{tabular}{ccc}
\hline Equations & Correlation coefficient $(\boldsymbol{r})$ & $\boldsymbol{P}$ \\
\hline $\mathrm{GA}=44.76-(4.34 \times \mathrm{ICCD})$ & 0.85 & $<0.05$ \\
$\mathrm{GA}=70.2-(3.8 \times \mathrm{BPD})$ & 0.91 & $<0.05$ \\
\hline
\end{tabular}

GA, gestational age; ICCD, inner chorionic cavity diameter (embryonic stage); BPD, biparietal diameter (fetal stage).

Source: Authors.

\subsection{Biparietal diameter and heart rate should be analyzed together}

According to Table 3, the analysis based on fetal parameters such as biparietal diameter (BPD) and heart rate (HR) has shown significant ultrasound findings at 48 h, 24 h, and 6 h before elective cesarean section. BPD values have significantly 
increased from $48 \mathrm{~h}$ to $6 \mathrm{~h}$ before delivery among the three evaluated times. BPD has increased by $0.11 \pm 0.03 \mathrm{~cm}$ between 48 $\mathrm{h}$ and $24 \mathrm{~h}$ before cesarean section, as well as by $0.14 \pm 0.05 \mathrm{~cm}$, between $24 \mathrm{~h}$ and $6 \mathrm{~h}$ before cesarean section. Pre-delivery BPD was $\geq 3 \mathrm{~cm}$ (minimum: $3.00 \mathrm{~cm}$ and maximum: $3.17 \mathrm{~cm}$ ) $6 \mathrm{~h}$ before cesarean section, regardless of the number of puppies.

Although heart rate values did not differ between $48 \mathrm{~h}$ and $24 \mathrm{~h}$ before cesarean section, these values have significantly reduced during the last $6 \mathrm{~h}$ before delivery. During this period, fetal HR ranged from 165 beats per minute (bpm) to $210 \mathrm{bpm}$, most of the litter presented HR values <200 bpm. On the other hand, there was not statistically significant difference in intestinal peristalsis among scores analyzed at different prepartum times.

Results of experiment n. 2 have shown that fetal parameters such as BPD and HR should be analyzed together in order to help making decisions about the proper time to perform elective cesarean section, with emphasis on the incidence of BPD larger than $3 \mathrm{~cm}$ and HR $<200 \mathrm{bpm}$ in English Bulldog puppies, within the last $6 \mathrm{~h}$ before delivery.

Table 3 - Evaluation of fetal parameters at three different times before elective cesarean section in healthy English Bulldog bitches.

\begin{tabular}{cccc}
\hline \multirow{2}{*}{ Fetal parameters* } & \multicolumn{3}{c}{ Ultrasound evaluation ** } \\
\cline { 2 - 4 } & $\mathbf{4 8}$ hours & $\mathbf{2 4}$ hours & 6 hours \\
\hline Biparietal diameter - BPD $(\mathrm{cm})$ & $2.83 \pm 0.04^{\mathrm{a}}$ & $2.94 \pm 0.04^{\mathrm{b}}$ & $3.08 \pm 0.05^{\mathrm{c}}$ \\
Heart rate - HR (bpm) & $233.16 \pm 8.13^{\mathrm{a}}$ & $222.12 \pm 13.33^{\mathrm{a}}$ & $190.55 \pm 10.86^{\mathrm{b}}$ \\
Intestinal peristalsis (scores) & $1 \pm 1^{\mathrm{a}}$ & $2 \pm 1^{\mathrm{a}}$ & $2 \pm 1^{\mathrm{a}}$ \\
\hline
\end{tabular}

*Parameters analyzed by measuring the parallel distance between parietal bones (biparietal diameter), heart rate per minute (bpm for heart rate), and bowel movements, which were classified as absent (score 0), light (score 1), moderate (score 2) and evident (score 3 ).

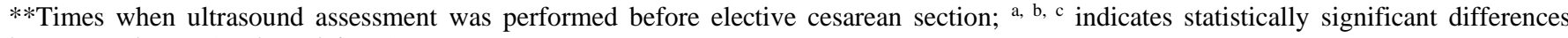
between columns (evaluated times).

Source: Authors.

\section{Discussion}

Species-specific formulas or specific size/breed can be used to get higher accuracy in predicting gestational age through ultrasound (Luvoni, 2013), although there are recommendations to use formulas developed for medium-sized dogs in large-sized and giant dogs (Socha et al., 2015). Gestational age has been estimated for breeds classified as small- $(\leq 10 \mathrm{~kg}$ ) and medium- (> $10 \mathrm{~kg}$ ) sized (Luvoni \& Grionni, 2000; Lopate, 2008), and even for large-sized and giant breeds (Beccaglia \& Luvoni, 2012; Alonge et al., 2016). With respect to specific canine breeds, studies have estimated GA in Labrador Retriever (England et al., 1990; Gül et al., 2000), Golden Retriever (England et al., 1990), Beagle (Gül et al., 2000), Yorkshire (Jabin et al., 2007), American Cocker Spaniel and Chow-Chow (Melo et al., 2006), Jack Russell Terrier (Luvoni \& Grionni, 2000), Rottweiler (Teixeira et al., 2009) and German Shepherd (Groppetii et al., 2015).

The current study was the first to evaluate GA estimates in brachycephalic English Bulldogs. This breed is highly prone to dystocia (Jackson, 2004; Bergstrom et al., 2006; Dobak et al., 2018), due to incidence of dorsum-ventrally flattened pelvis in bitches belonging to this species, as well as to disproportionately large fetal skull (Johnston et al., 2001; LindeForsberg, 2005; Evans \& Adams, 2010; Wydooghe et al., 2013), which ends up leading to the need of emergency (Jutkowitz, 2005) or elective cesarean sections (Dobak et al., 2018).

Although breed is reported to be determining factor for gestation duration and litter size (Okkens et al., 2001) and litter size is reported to lead to longer pregnancy duration (Eils et al., 2005; Groppetti et al., 2015; Alonge et al., 2016), the number of conceptuses did not influence pregnancy duration in the current study. Assumingly, the number of English Bulldog puppies would not influence pregnancy duration because this breed is not highly prolific. However, the canine bitches 
investigated in the present study were subjected to elective cesarean sections, and it was not possible estimating the influence of the number of conceptuses on gestational duration.

Delivery date or gestational age can be estimated by measuring gestational vesicle diameter or chorionic cavity diameter (Yeager et al., 1992; Luvoni \& Grioni, 2000), biparietal diameter (Kutzler et al., 2003), thoracic and abdominal, body lengths (England et al., 1990), placental thickness (Maldonado et al. 2012) and diencephalon-telencephalic vesicle diameter (Beccaglia et al., 2008). However, only ICCD and BPD measurements were evaluated in the current study because they provide accurate results to estimate gestational age at embryonic and fetal stage, respectively (Kutzler et al., 2003; Luvoni \& Beccaglia, 2006; Lopate, 2008; Michel et al., 2011). These parameters were sufficient to measure GA in healthy English Bulldog bitches since pregnancy duration calculated through the adopted formulas was equivalent to that of hormonal progesterone dosages.

Although the incidence of complications during parturition in English Bulldogs remains unknown, most owners and breeders often make the option for elective cesarean section due to fear of dystocic births and, consequently, to avoid litter loss. Thus, ultrasound is an important method used to assess fetal maturity parameters (Carvalho, 2014; Nyland \& Mattoon, 2015). However, few parameters are reliable and breed-specific, due to the subjectivity of this assessment. Based on evaluations of fetal growth parameters (BPD), HR and intestinal peristalsis performed in the current study, it is possible emphasizing that the joint evaluation of BPD and HR is highly recommended for decision-making about the proper time to perform elective cesarean sections in English Bulldog bitches.

Intrauterine fetal growth can be monitored by measuring fetal structures (Freitas et al., 2016). BPD is an accurate measurement taken at 40 days after conception, when bone mineralization has already started (Luvoni, 2013); thus, it is useful to estimate canine GA. This is the reason why BPD was herein assessed to estimate fetal maturity. It is important understanding breed-specific BPD in the pre-delivery period to make the right decision about the time to perform cesarean sections, since its value significantly increases in the last $48-6 \mathrm{~h}$ before delivery due to exponential fetal growth in the final third of pregnancy. In addition, BPD measuring through ultrasound enables inferring about fetuses in the litter presenting smaller size or delayed growth. However, so far, BPD was not accurate in predicting the best time to perform cesarean section in experimental dogs belonging to giant breeds, since they present great variation in litter size (Alonge et al., 2016) - further studies should be conducted to assess the influence of litter size on specific breeds, such as English Bulldog.

Mean fetal HR is $230 \mathrm{bpm}$; it reaches approximately $214 \mathrm{bpm}$ at early pregnancy, increases to approximately $238 \mathrm{bpm}$ at the $40^{\text {th }}$ gestational day, and declines close to parturition (Carvalho, 2014; Nyland \& Mattoon, 2015). However, normal fetal HR values or intervals before delivery in canine species remain unknown. The current findings have shown cardiac deceleration $6 \mathrm{~h}$ before delivery, sharp fetal HR decrease in a short time interval (at least $5 \mathrm{~min}$ ) and return to normal frequencies as indicative of eminent delivery (Giannico et al., 2015). Since HR below $180 \mathrm{bpm}$ is indicative of fetal distress (Johnson et al., 2001), values identified during the last $6 \mathrm{~h}$ before delivery were considered indicative of imminent delivery and, therefore, indicative of immediate cesarean delivery. Most fetuses in the current study were fully developed and presented reduced HR during this period, although their mothers did not show signs of active labor.

Finally, although intestinal peristalsis is key parameter used to assess complete canine fetal organogenesis and to evaluate fetal maturity (Gil et al., 2015), the current findings have shown that this parameter should not be evaluated in separate, at the time to make decisions about performing cesarean sections. Score 3 was identified in all three analyzed periods, including $48 \mathrm{~h}$ before delivery, and it evidenced early organogenesis. Since intestinal peristalsis evaluation is subjective, and its early visibility depends on the adopted ultrasound equipment (Gil et al., 2015), we do not recommend using ultrasound, in separate, to determine the functionality and maturation of this organ. 


\section{Conclusion}

Chorionic cavity and biparietal diameters are accurate measurements used to calculate gestational age in healthy English Bulldog bitches. Moreover, biparietal diameter measurements in association with heart rate are important and useful parameters to help identifying fetal maturity during ultrasound examinations before delivery.

\section{References}

Alonge, S., Beccaglia, M., Melandri, M., \& Luvoni, G. C. (2016). Prediction of whelping date in large and giant canine breeds by ultrasonography foetal biometry. Journal of Small Animal Practice, 57(9), 479-483.

Beccaglia, M., Faustini, M., \& Luvoni, G. C. (2008). Ultrasonographic study of deep portion of diencephalo-telencephalic vesicle for the determination of gestational age of the canine foetus. Reproduction in Domestic Animals, 43(3), 367-370.

Beccaglia, M. \& Luvoni, G. C. (2012). Prediction of parturition in dogs and cats: Accuracy at different gestational ages. Reproduction in Domestic Animals, 47(Suppl. 6), 194-196.

Bergstrom, A., Nodtvedt, A., Lagerstedt, A. S. \& Egenvall, A. (2006). Incidence and breed predilection for dystocia and risk factors for cesarean section in a Swedish population of insured dogs. Veterinary Surgery, 35(8), 786-791.

Carvalho, C.F. (2014). Ultrassonografia em Pequenos Animais (2nd ed). Roca.

Concannon, P. W., McCann, J. P. \& Temple, M. (1989). Biology and endocrinology of ovulation, pregnancy and parturition in the dog. Journal of Reproduction and Fertility, 39, 3-25.

Concannon, P. W. (2011). Reproductive cycles of the domestic bitch. Animal Reproduction Science, 124(3-4), 200-210.

Davidson, A. P. \& Baker, T. W. (2009). Reproductive ultrasound of dogs and tom. Topicals in Companion Animal Medicine, 24(2), 64-70.

De Carvalho, C. F., Magalhães, J. R., Martins, A. M., Guimarães, K. C. D. S., de Moraes, R. S., de Sousa, D. B., do Amaral, A. V. C. (2021). Pulsed-wave Doppler Ultrasound in canine reproductive system -Part 2: use in the routine. Research, Society and Development, 10(5), e52610515352, 1-11.

Dobak, T. P., Voorhout, G., Vernooij, J. C. M. \& Boroffka, S. A. E. B. (2018). Computed tomographic pelvimetry in English bulldogs. Theriogenology, 118, $144-149$.

Eilts, B. E., Davidson, A. P., Thompson, R. A., Paccamonti, D. L. \& Kappel, D. G. (2005). Factors influencing gestation length in the bitch. Theriogenology, $64(2), 242-251$.

England, G. C. W., Allen, W. E. \& Porter, D. J. (1990). Studies on canine pregnancy using B-mode ultrasound: development of the conceptus and determination of gestational age. Journal of Small Animal Practice, 31(7), 324-329.

Evans, K. M. \& Adams, V. J. (2010). Proportion of litters of purebred dogs born by Caesarean section. Journal of Small Animal Practice, 51(2), 113-118.

Feldman, E. C. \& Nelson, R. W. (2003). Canine and Feline Endocrinology and Reproduction (3rd ed.). W. B. Saunders.

Freitas, L. A., Mota, G. L., Silva, H. V. R., Carvalho, C. F. \& Silva, L. D. M. (2016). Can maternal-fetal hemodynamics influence prenatal development in dogs? Animal Reproduction Science, 172, 83-93.

Giannico, A. T., Gil, E. M., Garcia, D. A. \& Froes, T. R. (2015). The use of Doppler evaluation of the canine umbilical artery in prediction of delivery time and fetal distress. Animal Reproduction Science, 154, 105-112.

Gil, E. M., Garcia, D. A. \& Froes, T. R. (2015). In utero development of the fetal intestine: Sonographic evaluation and correlation with gestational age and fetal maturity in dogs. Theriogenology, 84(5), 875-879.

Gil, E. M., Garcia, D. A., Giannico, A. T. \& Froes, T. R. (2014). Canine fetal heart rate: Do accelerations or decelerations predict the parturition day in bitches? Theriogenology, 82(7), 933-941.

Groppetti, D., Vegetti, F., Bronzo, V. \& Pecile, A. (2015). Breed-specific fetal biometry and factors affecting the prediction of whelping date in the German shepherd dog. Animal Reproduction Science, 152, 117-122.

Gül, A., Kotan, C., Ugras, S., Alan, M. \& Gül, T. (2000). Transverse uterine incision non-closure versus closere: an experimental study in dogs. European Journal of Obstetrics, Gynecology, and Reproductive Biology, 88(1), 95-99.

Jabin, V. C. P., Finardi, J. C., Mendes, F. C. C., Weiss, R. R., Kozicki, L. E. \& Moraes, R. (2007). Uso de exames ultra-sonográficos para determiner a data da parturição em cadelas da raça Yorkshire. Archives of Veterinary Science, 12(1), 63-70.

Jackson, P. G. G. (2004). Handbook of Veterinary Obstetrics (2nd ed.). W. B. Saunders.

Johnston, S. D., Kustritz, M. V. R. \& Olson, P. N. S. (2001). Canine and Feline Theriogenology.: W. B. Saunders.

Jutkowitz, L. A. (2005). Reproductive emergencies. Veterinary Clinics of North America - Small Animal Practice, 35(2), 397-420. 
Research, Society and Development, v. 10, n. 10, e555101019091, 2021

(CC BY 4.0) | ISSN 2525-3409 | DOI: http://dx.doi.org/10.33448/rsd-v10i10.19091

Kutzler, M. A., Yeager, A. E., Mohammed, H. O. \& Meyers-Wallen, V. N. (2003). Accuracy of canine parturition date prediction using fetal measurements obtained by ultrasonography. Theriogenology, 60(7), 1309-1317.

Lamm, C. G. \& Makloski, C.L. (2012). Current advances in gestation and parturition in cats and dogs. Veterinary Clinics of North America - Small Animal Practice, 42(3), 445-456.

Linde-Forsberg, C. (2005). Abnormalities in pregnancy, parturition and the periparturient period. In: S. J. Ettinger \& E. C Feldman (Eds.), Textbook of Veterinary Internal Medicine: Diseases of the Dog and Cat (6 ${ }^{\text {th }}$ ed., pp. 1655-1667). St. Louis, Elsevier Saunders.

Lopate, C. (2008). Estimation of gestational age and assessment of canine fetal maturation using radiology and ultrasonography: a review. Theriogenology, 70(3), 397-402.

Luvoni, G. C. (2013). Ultrasonographic study of gestation in dogs and cats. Brazilian Journal of Animal Reproduction, 37(2), 172-173, 2013.

Luvoni, G. C. \& Beccaglia, M. (2006). The prediction of parturition date in canine pregnancy. Reproduction in Domestic Animals, 41(1), 27-32.

Luvoni, G. C. \& Grioni, A. (2000). Determination of gestational age in medium and small size bitches using ultrasonographic fetal measurements. Journal of Small Animal Practice, 41(7), 292-294.

Maldonado, A. L. L., Araujo Júnior, E., Mendonça, D. S., Nardozza, L. M. M., Moron, A. F. \& Ajzen, S. A. (2012). Ultrasound Determination of Gestational Age Using Placental Thickness in Female Dogs: An Experimental Study. Veterinary Medicine International, 2012 (850867), 1-7.

Melo, K. C. M., Souza, D. M. B., Teixeira, M. J. C. D. S., Amorim, M. J. A. A. L. \& Wischral, A. (2006). Fetometria ultra-sonográfica na previsão da data do parto em cadelas das raças Cocker Spaniel Americano e Chow-Chow. Ciência Veterinária nos Trópicos, 9(1), 23-30.

Michel, E., Spörri, M., Ohlerth, S. \& Reichler, I. (2011). Prediction of parturition date in the bitch and queen. Reproduction in Domestic Animals, 46(5), 926932.

Nyland, T. G., Mattoon, J. S. (2015). Small Animal Diagnostic Ultrasound (3rd ed.). St. Louis: Elsevier.

O’Neill, D. G., O'Sullivan, A. M., Manson, E. A., Church, D. B., Boag, A. K., McGreevy, P. D. \& Brodbelt, D. C. (2017). Canine dystocia in 50 UK firstopinion emergency-care veterinary practices: prevalence and risk factors Veterinary Record, 181(4): 88.

Okkens, A. C., Teunissen, J. M., Van Osch, W., Van Den Brom, W. E., Dieleman, S. J., Kooistra, H. S. (2001). Influence of litter size and breed on the duration of gestation in dogs. Journal of Reproduction and Fertility - Supplement, 57, $193-197$.

Pereira A. S., Shitsuka, D. M., Parreira, F. J. \& Sitsuka, R. (2018). Metodologia da pesquisa científica. UFSM.

Socha, P., Janowski, T. \& Bancerz-Kisiel, A. (2015). Ultrasonographic fetometry formulas of inner chorionic cavity diameter and biparietal diameter for medium-sized dogs can be used in giant breeds. Theriogenology, 84(5), 779-783.

Teixeira, M. J., De Souza, D. M. B., Melo, K. C. M. \& Wischaral, A. (2009). Estimativa da data do parto em cadelas rottweiler através da biometria fetal realizada por ultrassonografia. Ciência Animal Brasileira, 10(3), 853-861.

Wydooghe, E., Berghmans, E., Rijsselaere, T. \& Van Soom, A. (2013). International breeder inquiry into the reproduction of the English bulldog. Vlaams Diergeneeskundig Tijdschrift, 82(1), 38-43.

Yeager, A. E., Mohammed, H. O., Meyers-Wallen, V., Vannerson, L., Concannon, P. W. (1992). Ultrasonographic appearance of the uterus, placenta, fetus, and fetal membranes throughout accurately timed pregnancy in beagles. American Journal of Veterinary Research, 53(3), 342-351. 